MUDRA: Journal of Finance and Accounting, Volume 4, Issue 2, July-December 2017, pp. 167-184 doi: 10.17492/mudra.v4i02.11453

\title{
Impact of Stock Market Reforms on Investors' Confidence and Behaviour in Indian Stock Market: A Case Study of Tamil Nadu
}

\author{
M. Bhoopal* and G. Prabakaran**
}

\begin{abstract}
This paper examines the impact of stock market reforms on investors' confidence and behaviour in Indian stock market. The research design applied for the study is analytical and descriptive in nature. Both the primary and secondary data were used in this study. The primary data were collected from investors of Indian securities market covering 10 city corporations of Tamil Nadu. Cronbach alpha test, Split - half reliability test, Confirmatory Factor Analysis (CFA), Content and Construct Validity were applied to ensure the validity and reliability of data collection instrument. Primary data were analysed using Structural Equation Modeling (SEM). It is suggested that the regulating body may take suitable measures to consider these 12 statements while designing investors' educational programme with respect to these 12 variables is vital to enhance investors' confidence towards stock market reforms. Suitably designed educational programme will instil confidence among the investors with respect to stock market reforms in Indian securities market. High level of confidence will help the investors to take right investment decisions at right time.
\end{abstract}

Keywords: Stock market reforms; Investors' Confidence; Behaviour; SEBI; BSE; NSE.

\subsection{Introduction}

The Indian securities market has been attracting considerable attention in recent years, especially after the liberalisation of the economy. Since India started its economic reforms in the early 1990s, it has ensured its current position as one of the largest developing countries in the world. The financial sector in India has developed quite significantly in both size and sophistication.

*Corresponding author; Assistant Professor, Department of MBA, Manonmaniam Sundaranar University, Tirunelveli, Tamil Nadu, India. (Email id: bhoopalmsu@msuniv.ac.in)

**Assistant Professor, Department of BBA, Government Arts College, Dharmapuri, Tamil Nadu, India. (Email id: prabakaranjayam@yahoo.com) 
A major fillip to strengthen the financial system was given by the rapid expansion of the stock market, especially in the later part of the 1980s and subsequently by initiating financial sector reforms on the recommendation of the high - powered Narasimham Committee in 1992 - 93. Wide ranging financial reform measures were implemented since then to make the financial system more oriented, thereby aiming at increasing its efficiency. The Indian capital market in general and stock market in particular have witnessed radical and metamorphic changes which have occurred in response to these domestic initiatives coupled with the emerging liberal and deregulated global financial environment.

India has achieved considerable financial deepening in recent years, owing largely to the reforms and the foreign capital the country has attracted. McKinsey (2006) points out that till 2001, the reforms had not produced much financial deepening, with the total value of financial assets never exceeding the GDP by more than $10 \%$. Then deepening started in a major way by 2004, the total value of financial assets stood at $160 \%$ of the GDP which further exploded to $305 \%$ in 2007 . This means a CAGR (Compound Annual Growth Rate) of about 11\% between 2001 and 2007.

During this period equity markets showed the most stunning increase (from 23\% of GDP to $165 \%$, a CAGR of as much as 39\%) and corporate bonds showed equally remarkable gains but on significant base (1\% to 73\%; a CAGR of 39\%) (Chakrabarti, 2010). Government securities showed a relatively moderate rise (27\% to $63 \%$; a CAGR of $15 \%$ ) while bank deposits rose at a snail's pace ( $57 \%$ to $69 \%$; a CAGR of $3 \%$ ). Therefore, retaining investors' confidence is of great importance for the stability of capital market in particular and Indian economy in general. A major proportion of investment in primary and secondary markets comes from small investors in India. Whereas, in developed countries, institutional investors constitute a major proportion of investment. Small investors approach primary markets for both regular income and capital gains. When they invest in companies either at par or at a reasonable premium they will receive dividends and appreciation in financial markets. Securities market is important as it is significantly related with the index of industrial production.

\subsection{Statement of the Problem}

Studies have indicated that equity markets suffer serious inadequacies as a mechanism for raising capital. There are more speculations by investors rather than investment orientation. The major problems in Indian primary market are lack of transparency, no control on intermediaries, higher issue price compared with fundamentals, inefficient grievance redressal machinery and political interference. Thus 
primary markets play a prominent role in bringing investments into equity markets. Also the report indicates that $80 \%$ of equity investor households were first generation investors. The report has also indicated that there is a decrease in preference for equity due to the losses made in investments by the investors in equity markets. These losses in primary market are due to lower market price after listing. Penetration level of the financial service sectors continues to be extremely low. There is a need for a rigorous effort to extract effectively the full potential of India's savings, which stands at an impressive 34\% of the GDP. As an July 2011, only one percent of the households had invested in mutual funds and a mere $0.72 \%$ of households in equity shares. (Indian Financial Service (Outlook, 2012).The corporate bond market has remained relatively underdeveloped. This has been the result of the dominance of the banking system combined with the weakness in market infrastructure and the inherent complexities. This study identifies the gap between investors' confidence and behaviour with respect to stock market reforms in Indian securities market.

\subsection{Review of Literature}

Pangano (1993) shows that regulatory and institutional factors may influence the functioning of stock markets. For example, mandatory disclosures of reliable information about firms may enhance investor participation and regulations that instil investor confidence in brokers which should encourage investment and trading in stock market. Radha (1995) in her study titled 'A Study of Investment Behaviour of Investors of Corporate Securities' (1995) has examined the investment plan of corporate security investors in Tamil Nadu. The analysis revealed that the largest segment of the sample was constituted by young generation investors. They were generally better educated and male investors were reported to dominate the investment scene. Salaried group investors were reported to dominate the share ownership position. Also, major parts of the samples were found having savings but their capacity of saving was very limited. While probing the pre-investment behaviour and investment objectives, it was found that investors formed certain primary objectives and gave importance to them while making investment plans.

Gupta (1996) has indicated that from the angle of investor protection, the regulation of the new issue market is important for several reasons. The number of small investors in new issue market is massive. Most of new investors make their first entry into equity investments via the new issue market. So retaining common investor confidence in primary markets is important. Loong (2000) while addressing Financial Institutions in Bangkok, stressed the importance of rebuilding investor confidence for 
prosperity of ASEAN countries. He indicated that for investor confidence, rebuilding of sound fundamentals, dealing with capital account risks, economic co-operation among ASEAN Countries, corporate restructuring, banking sector reforms and improvement of political and social conditions are important. Shahid (2008) while discussing the last melt down of the capital market across the globe, stated that markets have become more complex, institutionalized, and more and more cross border investments are pouring in. The author has stressed the need for investor education and their confidence as today investors are attracted by the depth, quality and integrity of markets, besides expecting valuable returns. With the extensive usage of technology, in particular, the internet, investors are now able to access a wider range of investment opportunities across countries, regions and continents. Furthermore, investors have become savvy, demanding more reliable, useful and timely information, and advocated that investor education should become a top priority not only to market regulators but also for stock exchanges.

Waweru et al. (2008) investigated the role of behavioural finance and investor psychology in investment decision making and identified that certain behavioural factors affected the decision making behaviour of the investors. It acquired importance because in stock market, decisions are not guided by rationality or prudence, but the emotions, greed and insufficient knowledge in stock market operations in the highly overloaded information environment. Swarup (2010) identified safety and tax savings as the important factors affecting investment in various avenues by the investor and developed strategies for enhancing common investor confidence such as good return, transparency, investor education, guidance etc. Warne (2012) attempted to understand the behaviour of individual investor in stock market, specifically their attitude and perception with respect to the stock market. A survey was conducted to attain the objectives of the study. Respondents were classified into different categories on the basis of income, profession, education status, sex and age. Primary data were collected from a sample around 50 investors of Ambala district of Haryana state. Finally it was found out that there are different factors which affect the investment behaviour of individual investors such as their awareness level, duration of investment etc. The study reveals that the respondents integrate the objectives of saving with the factors influencing the saving and the sources of information for decision making. The annual income and the annual saving are given importance of consideration by the respondents, because the level of income decides the level of savings. Today's investors are fully aware of the stock market. The market movements affect the investment pattern of investors in the stock market. Qadri and Shabbir (2014) studied the impact of two biases, overconfidence and illusion of control on the investor's decisions on the Islamabad Stock Exchange. Researchers used 
questionnaire for data collection. The study revealed that over confidence and illusion of control bias have a lot of impact on investors' decision in ISE. The study also showed that male are more overconfident than female and Investors do not focus much on fundamental or technical analysis while taking their decisions.

\subsection{Objectives of the Study}

The study intends to achieve the following objectives:

(i) To study the socio-economic profile of the respondents from city corporations of Tamil Nadu.

(ii) To ascertain the impact of stock market reforms on investors' confidence and behaviour in Indian stock market.

\subsection{Research Methodology}

The research methodology includes nature of the study, nature of the data, data collection instrument, sample size determination, sampling procedure, hypotheses, period of the study, area of the study and framework of data analysis.

Nature of the study: The research design applied for this study is analytical and descriptive in nature.

Nature of the data: Both the primary and secondary data were used in this study. The primary data were collected from investors of Indian securities market in 10 city corporations of Tamil Nadu. Secondary data were collected from reports published by the Securities and Exchange Board of India (SEBI), National Stock Exchange (NSE), Over the Counter Exchange of India (OTCEI), Bombay Stock Exchange (BSE), Association of Mutual Funds in India (AMFI) and various regional stock exchanges. Secondary data were also collected from journals, magazines, periodicals and dailies. The secondary data was very useful to identify the research problem in clear manner and to evolve the research model appropriately. In addition, the data collection instrument (Interview Schedule) was designed with the help of reviewing the previous studies (Review of Literature) extensively.

Data collection instrument: The questions in the interview schedule were designed according to the statement of the problem and objectives of the study. The variables identified from review of literature were taken into account while drafting the interview schedule. The opinion from a panel of members comprising experts in the field of stock market, security analysis, portfolio management, statistics, management, economics, commerce and psychology was sought for at every stage of designing the final interview 
schedule. Cronbach alpha test, Split half - reliability test, Confirmatory Factor Analysis (CFA), Content validity and Construct validity were applied to ensure the validity and reliability of data collection instrument.

Hypothesis: There is a positive impact on investors' confidence towards stock market reforms in Indian securities market on investors' behaviour.

Framework of data analysis: Structural Equation Modeling was applied to ascertain the impact of stock market reforms on investors' confidence and behavior in Indian stock market.

\subsection{Scope of the study}

This study considers various reforms made in Indian securities market from time to time since early 1990s. This study is an eye opener for the investors of Indian securities market to measure the effectiveness of reforms in Indian securities market and alsoto ascertain the relationship between investors' confidence and investors' behaviour towards Indian securities market.

\subsection{Area of the study}

Respondents were selected from 10 city corporations of Tamil Nadu. They are Chennai, Coimbatore, Erode, Madurai, Salem, Tiruchirapalli, Tirunelveli, Tiruppur, Tuticorin and Vellore.

\subsection{Limitations of the study}

The following are the limitations of the study:

(i) The study is confined to 10 city corporations of Tamil Nadu only. Other areas of Tamil Nadu are excluded from the study.

(ii) The study is restricted to analyse the stock market reforms on investors' confidence and behaviour towards Indian securities market only. Other aspects of stock market as well as investors are excluded from the study.

\subsection{Data analysis}

Data analysis includes the following two important areas:

(i) Socio-economic profile of the respondents in select city corporations of Tamil Nadu.

(ii) Stock market reforms on investors behaviour and confidence.

\subsection{Socio-economic profile of the respondents}

Socio-economic profile of the respondents and the impact of stock market reforms on investors' confidence and behaviour. To study the socio-economic profile of 
investors who have invested in Indian securities, percentage analysis is applied. The socio - economic variables such as gender, age, marital status, annual income, monthly savings, and savings objectives are considered for the study.

\subsubsection{Gender of the Respondents}

The details related to the gender of the respondents are furnished in Table 1. It could be seen from Table 1 that 83.6 percent of the respondents are male and 16.4 percent of the respondents are female. It is observed from the analysis that majority of the respondents $(83.6 \%)$ are male who have invested their money in various securities in Indian stock market.

Table 1: Gender of the Respondents

\begin{tabular}{|c|c|c|}
\hline Gender & Frequency & Percent \\
\hline Male & 336 & 83.6 \\
\hline Female & 66 & 16.4 \\
\hline Total & $\mathbf{4 0 2}$ & $\mathbf{1 0 0 . 0}$ \\
\hline
\end{tabular}

Source: Primary Data

\subsubsection{Age of the respondents}

Age of the respondents is classified into six categories such as less than 20 years, 21-30 years, $31-40$ years, $41-50$ years, $51-60$ years and above 60 years. The details are given in Table 2. It is seen from Table 2 that 39.1 percent of the respondents belong to the age group of 31-40 years, 33.6 percent of the respondents belong to the age group of 21-30 years, 16.9 percent of the respondents belong to the age group of 41-50 years. Similarly 5.5 percent of the respondents fall in the category of 51-60 years, 2.7 percent of the respondents fall in the category of above 60 years and only 2.2 percent of the respondents fall in the category of less than 20 years. It is found from the analysis that $39.1 \%$ of the respondents belong to the age group of 31-40 years.

Table 2: Age of the Respondents

\begin{tabular}{|l|c|c|}
\hline \multicolumn{1}{|c|}{ Age of the Respondents } & Frequency & Percent \\
\hline Less than 20 Years & 9 & 2.2 \\
\hline 21-30 Years & 135 & 33.6 \\
\hline 31-40 Years & 157 & 39.1 \\
\hline 41-50 Years & 68 & 16.9 \\
\hline 51-60 Years & 22 & 5.5 \\
\hline Above 60 Years & 11 & 2.7 \\
\hline \multicolumn{1}{|c|}{ Total } & $\mathbf{4 0 2}$ & $\mathbf{1 0 0 . 0}$ \\
\hline
\end{tabular}

Source: Primary Data 


\subsubsection{Marital status of the respondents}

The details regarding the marital status of the respondents are furnished in Table 3. It could be inferred form table 3 that 64.2 percent of the respondents are married and 35.8 percent of the respondents are unmarried. It is important to note that majority of the respondents $(64.2 \%)$ are married investors.

Table 3: Marital Status of the Respondents

\begin{tabular}{|c|c|c|}
\hline Marital Status & Frequency & Percent \\
\hline Married & 258 & 64.2 \\
\hline Unmarried & 144 & 35.8 \\
\hline Total & $\mathbf{4 0 2}$ & $\mathbf{1 0 0 . 0}$ \\
\hline Source: Primary Data
\end{tabular}

\subsubsection{Annual income of the respondents}

Annual income of the respondents is given in the Table 4. The range of the annual income is of less than Rs 3 lakhs, Rs 3 lakhs to less than Rs 6 lakhs, Rs 6 lakhs to less than Rs 9 lakhs and Rs 9 lakhs and above. It is seen from Table 4 that 57.7 percent of the respondents' income is less than Rs 3 lakhs, 29.1 percent of the respondents' income range is between Rs 3 lakhs to less than Rs 6 lakhs, 7.7 percent of the respondents' income range is between Rs 6 lakhs to less than Rs 9 lakhs and only 5.5 percent of the respondents belong to the category of Rs 9 lakhs and above. It is noted from the analysis that majority of the respondents' (57.7\%) annual income is less than Rs 3 lakhs.

\section{Table 4: Annual Income of the Respondents}

\begin{tabular}{|l|c|c|}
\hline \multicolumn{1}{|c|}{ Annual Income } & Frequency & Percent \\
\hline Less than Rs 3 Lakhs & 232 & 57.7 \\
\hline Rs 3 Lakhs to less than Rs 6 Lakhs & 117 & 29.1 \\
\hline Rs 6 Lakhs to less than Rs 9 Lakhs & 31 & 7.7 \\
\hline Rs 9 Lakhs and above & 22 & 5.5 \\
\hline \multicolumn{1}{|c|}{ Total } & $\mathbf{4 0 2}$ & $\mathbf{1 0 0 . 0}$ \\
\hline
\end{tabular}

Source: Primary Data

\subsubsection{Monthly savings of the respondents}

The four categories of monthly savings are given in the following Table 5. The four categories are less than Rs 5,000, Rs 5,000 - less than Rs 10,000, Rs 10,000 - less than Rs 15,000 and Rs 15,000 and above. It is observed from table 5 that 32.1 percent of 
the respondents' savings is Rs 5000-less than Rs 10,000, 30.8 percent of the respondents' savings is less than Rs 5,000, 25.6 percent of the respondents' savings is above Rs 15,000 and only 11.4 percent of the respondents' savings is Rs 10,000 - less than Rs 15,000 . It is noted from the analysis that $32.1 \%$ of the investors have monthly savings ranging between Rs 5,000-less than Rs 10,000.

Table 5: Monthly Savings of the Respondents

\begin{tabular}{|c|c|c|}
\hline Monthly Savings & Frequency & Percent \\
\hline Less than Rs 5,000 & 124 & 30.8 \\
\hline Rs 5,000 to less than Rs 10,000 & 129 & 32.1 \\
\hline Rs 10,000 to less than Rs 15,000 & 46 & 11.4 \\
\hline Above Rs 15,000 & 103 & 25.6 \\
\hline Total & 402 & 100.0 \\
\hline
\end{tabular}

Source: Primary Data

\subsubsection{Savings objective of the respondents}

Savings objective of the respondents is given in Table 6. For this purpose savings objective is classified into eight categories such as retirement benefit, tax benefit, children's education, healthcare, purchase of property, children's marriage, combination of all the above six categories and others.

Table 6: Savings Objective of the Respondents

\begin{tabular}{|l|c|c|}
\hline \multicolumn{1}{|c|}{ Savings Objective } & Frequency & Percent \\
\hline Retirement Benefit & 14 & 3.5 \\
\hline Tax Benefit & 13 & 3.2 \\
\hline Children's Education & 28 & 7.0 \\
\hline Healthcare & 7 & 1.7 \\
\hline Purchase of Property & 126 & 31.3 \\
\hline Children's Marriage & 16 & 4.0 \\
\hline All the Above & 145 & 36.1 \\
\hline Others Total & 53 & 13.2 \\
\hline \multicolumn{2}{|c|}{ T02 } & $\mathbf{1 0 0 . 0}$ \\
\hline
\end{tabular}

Source: Primary Data

It can be seen from Table 6 that 36.1 percent of the respondents have collective savings objective i.e., more than a single objective, 31.3 percent of the respondents have invested for the purpose of purchase of property. 13.2 percent of the respondents have invested their money for other than the above purposes and 7 percent of the respondents 
have invested their money for children's education. It is also inferred that 4 percent of the respondents save their money for children's marriage, 3.5 percent of the respondents save their money for retirement benefit, 3.2 percent of the respondents save their money for tax benefit and only 1.7 percent of the respondents save their money with the objective of health care. It is clear from the analysis that $36.1 \%$ of the respondents prefer to save their money with the collective savings objectives than a single objective.

\subsection{Stock market reforms on investors behaviour and confidence}

Primary data were collected from 402 investor respondents covering 10 city corporations of Tamil Nadu. To study the relationship between investors' confidence and investors' behaviour towards reforms in Indian securities market, Structural Equation Modeling (SEM) is employed. For this purpose, 12 statements pertaining to investors' confidence are used. Figure 1 is a graphic presentation of the developed hypothetical model.

Figure 1: Conceptual Model

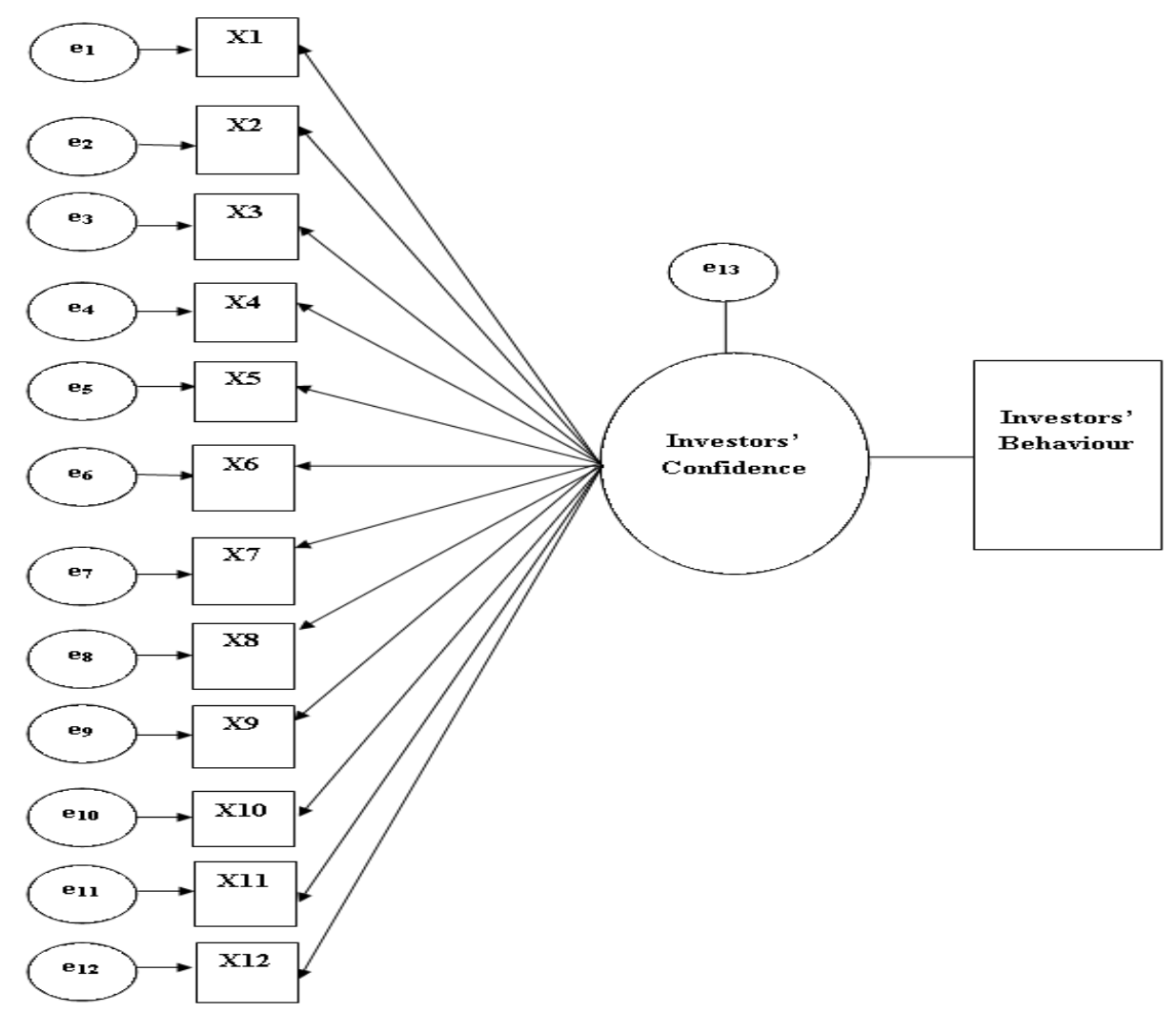


In Figure 1,

$\mathrm{X}_{1}=$ The movement of share prices has been stable enough to encourage investors to participate.

$\mathrm{X}_{2}=$ Indian stock markets are well regulated.

$\mathrm{X}_{3}=$ The demat system is convenient and cheap.

$\mathrm{X}_{4}=$ Adequate and reliable portfolio management services are available for individual investors.

$\mathrm{X}_{5}=$ Capital market in India is a safe haven for investors.

$\mathrm{X}_{6}=$ Risk is highlighted in Indian stock market so as to enable the investors to take decision.

$\mathrm{X}_{7}=$ Investors receive good quality advice from distributor/ broker.

$\mathrm{X}_{8}=$ Attending investor educational programme is beneficial for investment.

$\mathrm{X}_{9}=$ High regulatory control on broker/distributor.

$\mathrm{X}_{10}=$ The investor confidence leading to make simplification of investment in right financial assets.

$\mathrm{X}_{11}=\mathrm{In}$ the last few years, Indian economy is growing at good speed.

$X_{12}=$ The returns on the stock exchange are higher than those from other investments.

\subsubsection{Validity of the measurement}

To obtain non- standardized and standardized regression weights, a variance estimate for the residual errors and the squared multiple correlation of the dependent variable "Investors' Confidence" are calculated. In this case, the calculated value of chisquare test is 63.652 on 48 degrees of freedom, which gives a $\mathrm{P}$ - value of 0.065 and this model is a good fit for the analysis. The real strength of SEM is to estimate more complicated path models, with intervening variances between the independent and dependent variables and latent factor as well.

Table 7 shows the regression coefficient of the exogenous variables. It is noted that the critical ratio of $\mathrm{X}_{12}, \mathrm{X}_{11}, \mathrm{X}_{10}, \mathrm{X}_{9}, \mathrm{X}_{8}, \mathrm{X}_{7}, \mathrm{X}_{6}, \mathrm{X}_{5}, \mathrm{X}_{4}, \mathrm{X}_{3}, \mathrm{X}_{2}$, and $\mathrm{X}_{1}$ is above the table value and it is significant at 1 percent level. Among the selected 12 variables, all variables have influence on investors' confidence towards reforms in Indian securities market. Similarly, the investors' confidence has impact on investors' behaviour towards reforms in Indian securities market.

Table 8 portrays the CMIN for the "default model". A significant chi-square indicates satisfactory models fit. CMIN is a chi - square statistics comparing the default model and the independence model with the saturated model. Table 8 reveals that the default model has been associated at 1.326 percent with saturated model and on the other side the independence model has been associated at 13.218 percent with saturated model. 
178 | MUDRA: Journal of Finance and Accounting, Volume 4, Issue 2, Jul-Dec 2017

Table 7: Maximum Likelihood Estimates

\begin{tabular}{|c|c|c|c|c|c|c|c|}
\hline $\begin{array}{l}\text { Measured } \\
\text { Variables }\end{array}$ & & $\begin{array}{c}\text { Latent } \\
\text { Variables }\end{array}$ & Estimates & SE & C.R & $\mathbf{P}$ & Label \\
\hline $\begin{array}{c}\text { Investors' } \\
\text { Confidence }\end{array}$ & $\leftarrow$ & $\begin{array}{l}\text { Investors' } \\
\text { Behaviour }\end{array}$ & 3.365 & .330 & 10.193 & $* * *$ & \\
\hline$X_{12}$ & $\leftarrow$ & $\begin{array}{l}\text { Investors' } \\
\text { Confidence }\end{array}$ & 1.000 & & & $* * *$ & \\
\hline$X_{11}$ & 4 & $\begin{array}{l}\text { Investors' } \\
\text { Confidence }\end{array}$ & .370 & .085 & 4.348 & $* * *$ & \\
\hline$X_{10}$ & 4 & $\begin{array}{l}\text { Investors' } \\
\text { Confidence }\end{array}$ & .277 & .043 & 6.362 & $* * *$ & \\
\hline $\mathrm{X}_{9}$ & & $\begin{array}{l}\text { Investors' } \\
\text { Confidence }\end{array}$ & .649 & .069 & 9.452 & $* * *$ & \\
\hline$X_{8}$ & 4 & $\begin{array}{l}\text { Investors' } \\
\text { Confidence }\end{array}$ & .874 & .081 & 10.764 & $* * *$ & \\
\hline$X_{7}$ & & $\begin{array}{l}\text { Investors' } \\
\text { Confidence }\end{array}$ & .818 & .078 & 10.444 & $* * *$ & \\
\hline$X_{6}$ & & $\begin{array}{l}\text { Investors' } \\
\text { Confidence }\end{array}$ & .416 & .076 & 5.499 & $* * *$ & \\
\hline $\mathrm{X}_{5}$ & & $\begin{array}{l}\text { Investors' } \\
\text { Confidence }\end{array}$ & .976 & .069 & 14.170 & $* * *$ & \\
\hline $\mathrm{X}_{4}$ & & $\begin{array}{l}\text { Investors' } \\
\text { Confidence }\end{array}$ & .385 & .051 & 7.521 & $* * *$ & \\
\hline$X_{3}$ & & $\begin{array}{l}\text { Investors' } \\
\text { Confidence }\end{array}$ & .320 & .050 & 6.368 & $* * *$ & \\
\hline$X_{2}$ & $\leftarrow$ & $\begin{array}{l}\text { Investors' } \\
\text { Confidence }\end{array}$ & .476 & .058 & 8.198 & $* * *$ & \\
\hline $\mathrm{X}_{1}$ & 4 & $\begin{array}{l}\text { Investors' } \\
\text { Confidence }\end{array}$ & .506 & .078 & 6.528 & $* * *$ & \\
\hline
\end{tabular}

Source: Primary Data

Table 8: Model Fit Summary - CMIN

\begin{tabular}{|l|c|c|c|c|c|}
\hline \multicolumn{1}{|c|}{ Model } & NPAR & CMIN & df & P & CMIN/df \\
\hline Default Model & 43 & 63.652 & 48 & .065 & 1.326 \\
\hline Saturated Model & 91 & .000 & 0 & & \\
\hline Independence Model & 13 & 1030.988 & 78 & .000 & 13.218 \\
\hline \multicolumn{1}{|l}{ Source: Primary Data }
\end{tabular}

Source: Primary Data 


\subsubsection{Root mean square residue and goodness-of-fit index}

The Root Mean Square Residual (RMR) is the mean absolute value of the covariance residuals, which reflect the difference between observed and model estimated covariance. Specifically, RMR is the co-efficient which results from taking the square root of the mean of the squared residuals. The closer RMR is to 0 and better is the model fit. The GFI is the goodness-of-fit index and is equal to 1 (chi-square for the default model/chi-square for the null model). Table 9 indicates that the model is a good fit by the influence of RMR value 0.098. GFI (Goodness of Fit Index) refers to a fact that 97.6 percent has been fitted in default model for the proportion of variance-co-variance matrix, on the other hand, 58.5 percent fit in independence model.

Table 9: Root Mean Square Residue and Goodness-of-Fit Index

\begin{tabular}{|l|c|c|c|c|}
\hline \multicolumn{1}{|c|}{ Model } & RMR & GFI & AGFI & PGFI \\
\hline Default Model & .098 & .976 & .955 & .515 \\
\hline Saturated Model & .000 & 1.000 & & \\
\hline Independence Model & .560 & .585 & .516 & .502 \\
\hline
\end{tabular}

Source: Primary Data

\subsubsection{Baseline comparisons}

The NFI, Normed Fit Index, also known as 1 wa $\triangle$ developed as the alternative to CFI, Comparative Fit Index, is also known as the Bentler comparative Fit Index, which compares the existing model fit with the null model which assumes the latent variables correlate with independent variables. From Table 10 it is observed that the evidence of NFI (0.938) and CFI (0.984) are greater than 0.8 it means the latent variables correlate with independent variables.

Table 10: Baseline Comparisons

\begin{tabular}{|l|c|c|c|c|c|}
\hline \multicolumn{1}{|c|}{ Model } & $\begin{array}{c}\text { NFI } \\
\text { Delata1 }\end{array}$ & RFI Rho1 & $\begin{array}{c}\text { IFI } \\
\text { Delta 2 }\end{array}$ & TLI Rho 2 & CFI \\
\hline Default Model & .938 & .900 & .984 & .973 & .984 \\
\hline Saturated Model & 1.000 & & 1.000 & & 1.000 \\
\hline Independence Model & .000 & .000 & .000 & .000 & .000 \\
\hline
\end{tabular}

Source: Primary Data

\subsubsection{Root mean square error of approximation}

Root mean Square of approximation is the popular measure of fit, because it does not require comparison with the null model. It is one of the fit indexes less affected by sample size. There is good model fit if RMSEA is less than or equal to 0.05 . It is 
180 | MUDRA: Journal of Finance and Accounting, Volume 4, Issue 2, Jul-Dec 2017

noted from Table 11 that the RMSEA value is 0.029 which is less than 0.05 . Hence the model resulted as good fit.

Table 11: Root Mean Square of Approximation

\begin{tabular}{|l|c|c|c|c|}
\hline \multicolumn{1}{|c|}{ Model } & RMSEA & LOGO & H190 & PCLOSE \\
\hline Default Model & 0.029 & 0.000 & 0.046 & 0.982 \\
\hline Independence Model & 0.175 & 0.165 & 0.184 & 0.000 \\
\hline
\end{tabular}

Source: Primary Data

\subsubsection{Results}

Results of the structural equation model are given in Table 12.

Table 12: Boots Trapping

\begin{tabular}{|c|c|c|c|c|c|c|}
\hline \multicolumn{3}{|c|}{ Paths } & Estimates & SE & "t" Value & Results \\
\hline $\begin{array}{l}\text { Investors' } \\
\text { Confidence }\end{array}$ & & $\begin{array}{l}\text { Investors' } \\
\text { Behaviour }\end{array}$ & 12.981 & 1.003 & 12.946 & $\mathrm{H}_{13}$ Accepted \\
\hline$X_{12}$ & 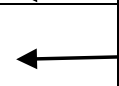 & $\begin{array}{l}\text { Investors' } \\
\text { Confidence }\end{array}$ & 1.225 & .088 & 13.935 & $\mathrm{H}_{12}$ Accepted \\
\hline$X_{11}$ & $<$ & $\begin{array}{l}\text { Investors' } \\
\text { Confidence }\end{array}$ & .575 & .042 & 13.713 & $\mathrm{H}_{11}$ Accepted \\
\hline $\mathrm{X}_{10}$ & & $\begin{array}{l}\text { Investors' } \\
\text { Confidence }\end{array}$ & .522 & .037 & 13.940 & $\mathrm{H}_{10}$ Accepted \\
\hline $\mathrm{X}_{9}$ & & $\begin{array}{c}\text { Investors' } \\
\text { Confidence }\end{array}$ & .481 & .035 & 13.797 & $\mathrm{H}_{9}$ Accepted \\
\hline $\mathrm{X}_{8}$ & & $\begin{array}{c}\text { Investors' } \\
\text { Confidence }\end{array}$ & .976 & .069 & 14.170 & $\mathrm{H}_{8}$ Accepted \\
\hline $\mathrm{X}_{7}$ & & $\begin{array}{c}\text { Investors' } \\
\text { Confidence }\end{array}$ & .718 & .057 & 12.590 & $\mathrm{H}_{7}$ Accepted \\
\hline $\mathrm{X}_{6}$ & & $\begin{array}{l}\text { Investors' } \\
\text { Confidence }\end{array}$ & .650 & .053 & 12.306 & $\mathrm{H}_{6}$ Accepted \\
\hline $\mathrm{X}_{5}$ & & $\begin{array}{l}\text { Investors' } \\
\text { Confidence }\end{array}$ & .343 & .039 & 8.772 & $\mathrm{H}_{5}$ Accepted \\
\hline $\mathrm{X}_{4}$ & & $\begin{array}{c}\text { Investors' } \\
\text { Confidence }\end{array}$ & .621 & .048 & 12.936 & $\mathrm{H}_{4}$ Accepted \\
\hline $\mathrm{X}_{3}$ & 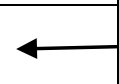 & $\begin{array}{l}\text { Investors' } \\
\text { Confidence }\end{array}$ & .385 & .028 & 13.910 & $\mathrm{H}_{3}$ Accepted \\
\hline $\mathrm{X}_{2}$ & & $\begin{array}{c}\text { Investors' } \\
\text { Confidence }\end{array}$ & 1.710 & .121 & 14.091 & $\mathrm{H}_{2}$ Accepted \\
\hline $\mathrm{X}_{1}$ & & $\begin{array}{l}\text { Investors' } \\
\text { Confidence }\end{array}$ & .940 & .085 & 11.001 & $\mathrm{H}_{1}$ Accepted \\
\hline
\end{tabular}


The following path analysis is used to prove the selected hypotheses (Figure 2).

\section{Figure 2: Structural Equation Modeling: Investors' Confidence and Investors' Behaviour}

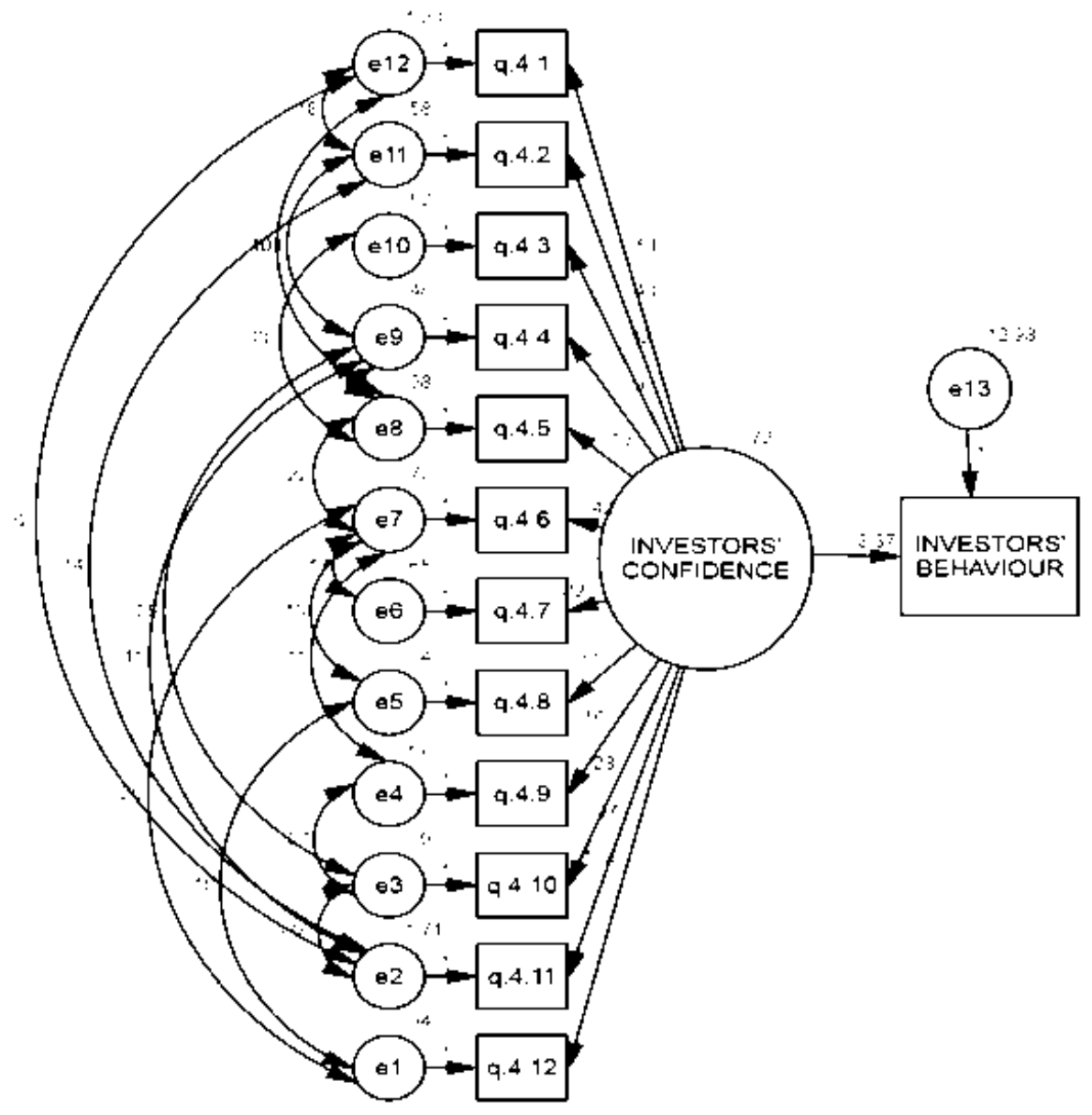

\subsubsection{Hypotheses testing and findings}

Table 13 represents the results of the testing of the hypotheses. It is observed from the structural equation modeling that measured variables with latent variable of investors' confidence in reforms in Indian securities market have positive relationship and also significant at 1 percent level. The analysis of the model, from the view point of 
the investors' confidence, suggests that all the measured variables have significant impact on investors' confidence in reforms in Indian securities market. It is also observed that investors' confidence has significant impact on investors' behaviour, towards stock market reforms in Indian securities market.

Table 13: Testing of Hypotheses

\begin{tabular}{|c|c|c|}
\hline Hypotheses & $\begin{array}{l}\text { Hypothetical } \\
\text { Relationship }\end{array}$ & Results \\
\hline $\begin{array}{l}\text { H1: There is a positive impact on investors' confidence and the } \\
\text { movement of share prices has been stable enough to encourage } \\
\text { investors to participate. }\end{array}$ & Positive & Confirmed \\
\hline $\begin{array}{l}\text { H2: There is a positive impact on investors' confidence and Indian } \\
\text { stock markets are well regulated. }\end{array}$ & Positive & Confirmed \\
\hline $\begin{array}{l}\text { H3: There is a positive impact on investors' confidence and the } \\
\text { demat system is convenient and cheap. }\end{array}$ & Positive & Confirmed \\
\hline $\begin{array}{l}\text { H4: There is a positive impact on investors' confidence and } \\
\text { adequate and reliable portfolio management services are available } \\
\text { for individual investors. }\end{array}$ & Positive & Confirmed \\
\hline $\begin{array}{l}\text { H5: There is a positive impact on investors' confidence and } \\
\text { Capital market in India is a safe haven for investors. }\end{array}$ & Positive & Confirmed \\
\hline $\begin{array}{l}\text { H6: There is a positive impact on investors' confidence and risk is } \\
\text { highlighted in Indian stock market so as to enable the investors to } \\
\text { take decision. }\end{array}$ & Positive & Confirmed \\
\hline $\begin{array}{l}\text { H7: There is a positive impact on investors' confidence and } \\
\text { Investors receive good quality advice from distributor/ broker. }\end{array}$ & Positive & Confirmed \\
\hline $\begin{array}{l}\text { H8: There is a positive impact on investors' confidence and } \\
\text { attending investor educational programme is beneficial for } \\
\text { investment. }\end{array}$ & Positive & Confirmed \\
\hline $\begin{array}{l}\text { H9: There is a positive impact on investors' confidence and High } \\
\text { Regulatory control on broker /distributor. }\end{array}$ & Positive & Confirmed \\
\hline $\begin{array}{l}\text { H10: There is a positive impact on investors' confidence and the } \\
\text { investor confidence leading to make simplification of investment } \\
\text { in right financial assets. }\end{array}$ & Positive & Confirmed \\
\hline $\begin{array}{l}\text { H11: There is a positive impact on investors' confidence and in } \\
\text { the last few years, Indian economy has been growing at good } \\
\text { speed. }\end{array}$ & Positive & Confirmed \\
\hline $\begin{array}{l}\text { H12: There is a positive impact on investors' confidence and the } \\
\text { returns on the stock exchange are higher than those from other } \\
\text { investments. }\end{array}$ & Positive & Confirmed \\
\hline $\begin{array}{l}\text { H13: There is a positive impact on investors' confidence and } \\
\text { investors' behaviour. }\end{array}$ & Positive & Confirmed \\
\hline
\end{tabular}




\subsection{Conclusion}

The research has mainly intended to study the influence of investors' confidence on investors' behaviour towards reforms in Indian securities market using structural equation modeling (SEM). It is found from the SEM that all the 12 measured variables have positive relationship with investors' confidence and in turn, investors' confidence has positive relationship with investors' confidence has positive relationship with investors' behaviour. Thus, it is clearly indicated that all the measured variables have significant impact on investors' confidence and indeed, investors' confidence has significant impact on investors' behaviour towards stock market reforms in Indian securities market. It is concluded that the regulating body may consider these 12 statements while designing investors' educational programme. Suitably designed educational programme will instil confidence among the investors' with respect to stock market reforms in Indian securities market. High level of confidence will help the investors to take right investment decisions at right time.

\section{References}

Chakrabarti, R. (2010). Financial development in India - Status and challenges.Retrieved from http://ssrn.com/abstract=1689493 or http://dx.doi.org/10.2139/ssrn.1689493

Gupta, L.C. (1996). Challenges before Securities and Exchange Board of India (SEBI). Economic and Political Weekly, 31(12), 751-757.

Loong, H. S. (2000). ASEAN post crisis: Rebuilding of confidence and prosperity. Retrieved fromhttps://www.bot.or.th/English/Press and Speeches/.../BGLee301100.pdf

Pangano, M. (1993). Financial markets and growth: An overview. European Economic Review, 37(2-3), 613-622.

Qadri, S. S. \& Shabbir, M. (2014). An empirical study of over confidence and illusion of control biases, impact on investor's decision making: An evidence from ISE. European Journal of Business and Management, 6(14), 38-45.

Radha, V. (1995). A study of investment behaviour of investors of corporate securities. Doctoral Thesis, Alagappa University, Karaikudi, India. 
184 | MUDRA: Journal of Finance and Accounting, Volume 4, Issue 2, Jul-Dec 2017

Shahid, S. F. A. (2008). Worldwide markets are jittering: More emphasis on investor education is required. White Paper written for the ETF and Indexing Investments, MENA Sep. 08 Conference.

Swarup, K. S. (2002). Role of mutual funds in developing investor confidence in Indian capital markets. South Asian Journal of Socio-Political Studies, 2(2), 58-60.

Warne, D.P. (2012). Investment behaviour of individual investor in stock market. Retrieved from www.mairec.org/IJRFM/Feb2012/21.pdf.

Waweru N. M., Evelyne, M. \& Elliana, E. (2008). The effects of behavioural factors in investment decision making: A survey of institutional investor operating at the Nairobi Stock Exchange. International Journal of Business and Emerging Markets, 1(1), 29-41. 